\title{
Streptococcus ictaluri sp. nov., isolated from Channel Catfish Ictalurus punctatus broodstock
}

\author{
Correspondence \\ P. Lynn Shewmaker \\ paw3@cdc.gov
}

\author{
P. Lynn Shewmaker, ${ }^{1}$ Alvin C. Camus, ${ }^{2}$ Tim Bailiff, ${ }^{1}$ Arnold G. Steigerwalt, ${ }^{1}$ \\ Roger E. Morey ${ }^{1}$ and Maria da Glória S. Carvalho ${ }^{1}$ \\ ${ }^{1}$ Centers for Disease Control and Prevention, Atlanta, GA 30333, USA \\ ${ }^{2}$ National Warmwater Aquaculture Center, 127 Experiment Station Road, Stoneville, \\ MS 38776, USA
}

During February 2002, September 2003, February 2004 and July 2004, four cases of suspected bacterial disease in Channel Catfish Ictalurus punctatus broodstock from four different commercial aquaculture operations in the Mississippi Delta were referred to the Aquatic Diagnostic Laboratory, Thad Cochran National Warmwater Aquaculture Center, Stoneville, Mississippi, USA. A streptococcallike organism was isolated from three of the catfish. Compatible lesions and cocci were seen in the cytology smears from a forth catfish; however, no viable bacteria could be cultured. The Streptococcus strains were associated with streptococcal arthritis, osteolysis, myositis and spinal meningitis in Channel Catfish broodstock. The isolates were initially identified as unidentified Streptococcus species and were referred to the Streptococcus laboratory in the Centers for Disease Control and Prevention (CDC) for further identification. Further evaluation of the strains (705-05, 706-05 and $707-05^{\mathrm{T}}$ ) by conventional biochemical testing, 16S rRNA sequencing and DNA-DNA hybridization studies revealed that these isolates represented a novel species of

Abbreviation: PYR, pyroglutamylaminopeptidase.

The GenBank accession number for the $16 \mathrm{~S}$ rRNA gene sequence of Streptococcus ictaluri $707-05^{\top}$ is DQ462421.

A minimum-evolution phylogenetic tree based on 16S rRNA gene sequences including Streptococcus ictaluri strains and the most closely related full-length type strains is available with the online version of this paper.
Streptococcus for which the name Streptococcus ictaluri sp. nov. is proposed.

The isolates were characterized phenotypically using conventional biochemical tests as described by Facklam \& Elliott (1995) and the Rapid ID 32 Strep system (bioMérieux) (Freney et al., 1992). Growth temperature studies at 25,30 and $35^{\circ} \mathrm{C}$ showed that the optimal temperature for growth was $30^{\circ} \mathrm{C}$; therefore, conventional biochemical and rapid tests were incubated at 30 and $35^{\circ} \mathrm{C}$. The phenotypic characteristics for S. ictaluri are listed in the species description. The Rapid ID32 Strep system was used as described by the manufacturer. The profile numbers inaccurately identified all three isolates as 'good identification' for Gemella haemolysans with $96 \%$ confidence. This error in identification is somewhat expected, since the strains were pyroglutamylaminopeptidase (PYR)-positive and were relatively inert in both conventional and rapid testing, as are Gemella species. A Gram stain can readily distinguish the two genera.

Table 1 shows some of the biochemical tests that can be used to distinguish between $S$. ictaluri and phylogenetically related Streptococcus species. The majority of streptococci are negative for PYR; however, S. ictaluri and most of the species that are phylogenetically similar are PYR-positive. Two species, Streptococcus canis and Streptococcus dysgalactiae subsp. dysgalactiae are differentiated from $S$. ictaluri by a negative PYR reaction. S. ictaluri is readily distinguished 
Table 1. Conventional tests useful for distinguishing S. ictaluri from phylogenetically related species

Abbreviations: HEM, haemolytic reaction on trypticase soy agar plus $5 \%$ sheep blood; PYR, pyrrolidonylarylamidase; $\mathrm{NaCl}$, growth in $6.5 \% \mathrm{NaCl}$ broth; ESC, aesculin hydrolysis; MAL, MAN, SBL, SUC and TRE, acid production in maltose, mannitol, sorbitol, sucrose and trehalose broths; $\mathrm{v}$, variable.

\begin{tabular}{|lcccccccccc|}
\hline Streptococcus species & HEM & PYR & NaCl & ESC & MAL & MAN & SBL & SUC & TRE \\
\hline S. ictaluri $707-05^{\mathrm{T}}$ & $\gamma$ & + & - & - & + & - & - & - & - \\
S. ${\text { iniae ATCC } 29178^{\mathrm{T}}}$ & $\beta$ & + & + & + & + & + & - & + & + \\
S. parauberis CCUG $39954^{\mathrm{T}}$ & $\gamma$ & + & - & + & + & + & + & + & + \\
S. canis ATCC $43496^{\mathrm{T}}$ & $\beta$ & - & + & + & + & - & - & + & $\mathrm{V}$ \\
S. pyogenes ATCC $12344^{\mathrm{T}}$ & $\beta$ & + & + & + & + & - & - & + & + \\
S. urinalis CCUG $41590^{\mathrm{T}}$ & $\gamma$ & + & + & + & - & - & - & + & + \\
S. uberis ATCC 19436 & $\gamma$ & + & + & + & + & + & + & + & + \\
S. dysgalactiae subsp. dysgalactiae & $\alpha$ & - & + & - & + & - & - & + & + \\
ATCC $43078^{\mathrm{T}}$ & & & & & & & & & \\
\hline
\end{tabular}

from the other phylogenetically similar streptococci based on its inactivity in most carbohydrate broths except for maltose and ribose. With the exception of Streptococcus urinalis, all the other Streptococcus strains tested in this study also produce acid from maltose, and all these species (including S. urinalis) produce acid from ribose. Streptococcus iniae, Streptococcus uberis, Streptococcus parauberis, Streptococcus pyogenes, and S. dysgalactiae subsp. dysgalactiae and S. canis are distinguished from S. ictaluri by the production of acid from sucrose and trehalose. S. urinalis produces acid from trehalose and $S$. canis produces acid from sucrose. S. ictaluri is negative for both these carbohydrates. Haemolytic reaction, growth in $6.5 \% \mathrm{NaCl}$, aesculin hydrolysis and acid production from mannitol and sorbitol are additional tests that are useful in differentiating S. ictaluri (Table 1).

The phylogenetic position of isolates 705-05, 706-05 and $707-05^{\mathrm{T}}$ was determined by comparative $16 \mathrm{~S}$ rRNA gene sequence analysis as described by Shewmaker et al. (2004). The identical sequences obtained from strains 705-05, 70605 and $707-05^{\mathrm{T}}$ were combined with related reference sequences from GenBank. These sequences were aligned with CLUSTAL in MEGA 3.1 (Kumar et al., 2004), trimmed to a $1377 \mathrm{bp}$ consensus and a neighbour-joining tree was created (Fig. 1). The same alignment was also used to create a minimum-evolution tree (Fig. S1, available as supplementary data with the online version of this paper). Reference strain 16S sequences from the CDC Streptococcus database were aligned in BioEdit with CLUSTAL and a distance matrix was created (data not shown). This analysis showed these isolates to be phylogenetically most similar to S. iniae, S. uberis, and S. parauberis with divergence ranging from 2.0 to $2.3 \%$. S. pyogenes, S. urinalis, S. dysgalactiae subsp. dysgalactiae and $S$. canis were included in the analysis and showed even greater differences (2.5-3.2 \% divergence). While the focus of this report is not an epidemiologic investigation, the identical $16 \mathrm{~S}$ rRNA sequence suggests that this could be the same clone, although the three isolates were separated by distance and time.
DNA-DNA relatedness studies were conducted as described by Shewmaker et al. (2004). Cultures were grown in 1 litre Todd-Hewitt broth and incubated for $24 \mathrm{~h}$ with the exception that $S$. ictaluri cultures were grown at $30^{\circ} \mathrm{C}$ instead of $35^{\circ} \mathrm{C}$. Cells were harvested and lysed as described by Teixeira et al. (1995), and DNA extraction, purification and DNA-DNA reassociation using the hydroxyapatite method were performed as described by Brenner et al. (1982). DNA reassociation experiments were performed at the optimal temperature $\left(55^{\circ} \mathrm{C}\right)$ and at the stringent temperature $\left(70^{\circ} \mathrm{C}\right)$ (Table 2$)$. The three catfish strains $(705-05$, 706-05 and $707-05^{\mathrm{T}}$ ) showed $92 \%$ DNA relatedness or greater at the optimal temperature, $89 \%$ or greater at the stringent temperature and a divergence of $\leqslant 0.5 \%$ when hybridized against the labelled type strain $\left(707-05^{\mathrm{T}}\right)$. The DNA relatedness of the type strain with S. canis, S. dysgalactiae subsp. dysgalactiae, S. iniae, S. parauberis, S. pyogenes, $S$. uberis and S. urinalis was $22 \%$ or less. These results confirm that the three S. ictaluri isolates are genetically distinct from these phylogenetically related species and clearly represent a novel species.

The DNA $\mathrm{G}+\mathrm{C}$ content was determined by thermal denaturation as described by Mandel et al. (1970). The $\mathrm{G}+\mathrm{C}$ content for strain $707-05^{\mathrm{T}}$ was $38.5 \mathrm{~mol} \%$.

Streptococcal species have been documented to cause disease in fish for decades (Hoshina et al., 1958; Robinson \& Meyer, 1966; Plumb et al., 1974; Baya et al., 1990; Perera et al., 1994, 1998; Romalde et al., 1999; Nomoto et al., 2004; Baeck et al., 2006); however, identification and taxonomic placement of the offending organisms have often been confused or incorrect. Although Chang \& Plumb (1996) investigated a $\beta$-haemolytic Streptococcus species isolated from Channel Catfish in 1991, streptococcosis has not been previously recognized as a disease of I. punctatus. While this study confirms the presence of a streptococcal disease in Channel Catfish, the potential significance of this emerging pathogen to the commercial catfish farming industry is currently unknown. Similarly, the zoonotic potential of 


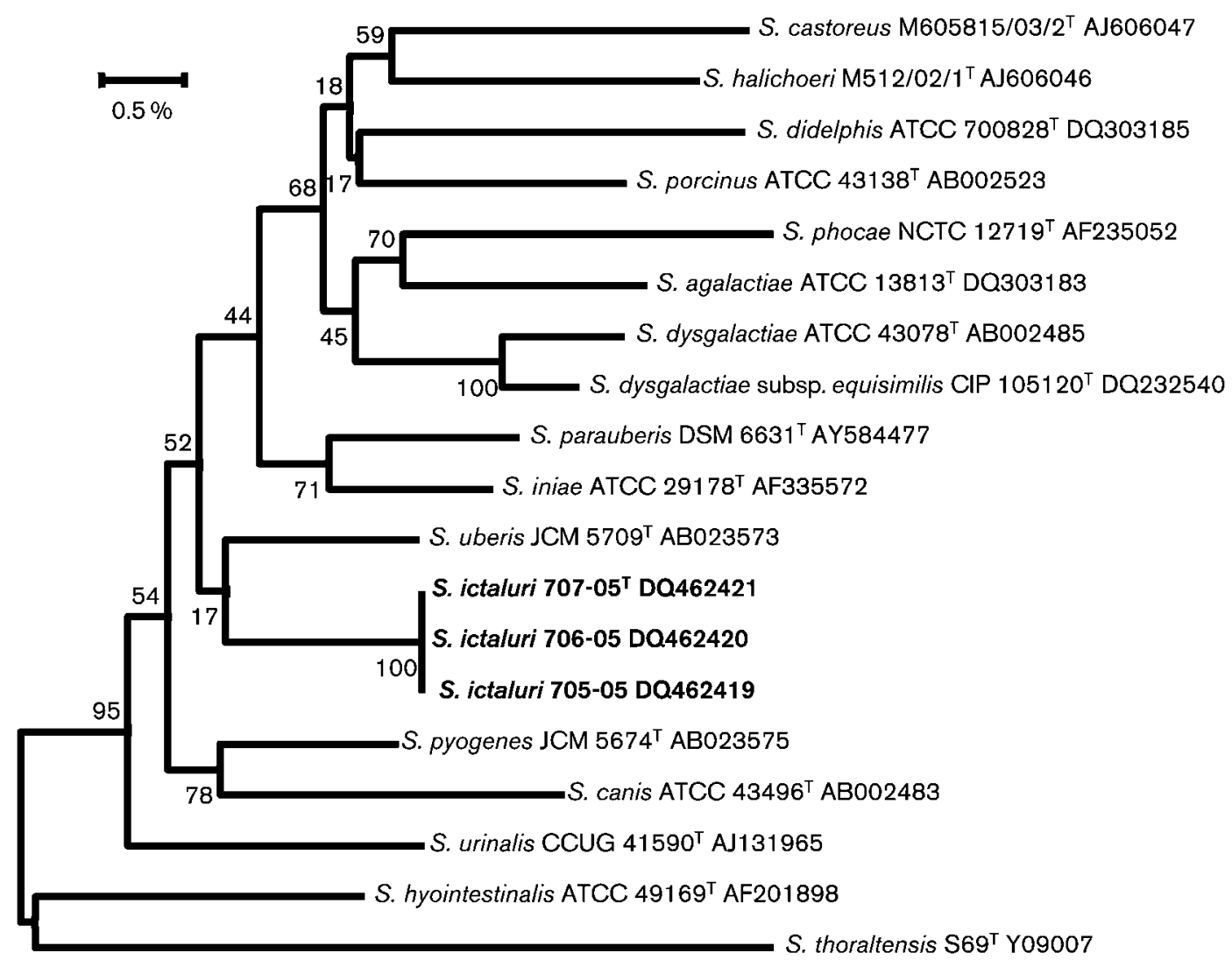

Fig. 1. Neighbour-joining phylogenetic tree based on $16 \mathrm{~S}$ rRNA gene sequences, including $S$. ictaluri strains and the most closely related type strains. Distances were estimated using the Kimura two-parameter model. Bootstrap values from 1000 replicates are displayed as percentages. Streptococcus thoraltensis $\mathrm{S} 9^{\top}$ was used to root the tree. Bar, $0.5 \mathrm{nt}$ substitutions per $100 \mathrm{nt}$.

Table 2. DNA-DNA relatedness between $S$. ictaluri strains and related type strains

\begin{tabular}{|c|c|c|c|}
\hline \multirow[t]{2}{*}{ Source of unlabelled DNA } & \multicolumn{3}{|c|}{ Results with labelled DNA from strain $707-05^{T_{\star}}$} \\
\hline & $\mathrm{RBR}$ at $55^{\circ} \mathrm{C}$ & $D$ & $\mathrm{RBR}$ at $70^{\circ} \mathrm{C}$ \\
\hline S. ictaluri $707-05^{\mathrm{T}}$ & 100 & 0.0 & 100 \\
\hline S. ictaluri 705-05 & 96 & 0.0 & 92 \\
\hline S. ictaluri 706-05 & 98 & 0.0 & 96 \\
\hline S. uberis ATCC $19436^{\mathrm{T}}$ & 12 & TNP & TNP \\
\hline S. iniae ATCC $29178^{\mathrm{T}}$ & 15 & TNP & TNP \\
\hline $\begin{array}{l}\text { S. dysgalactiae subsp. dysgalactiae } \\
\text { ATCC } 43078^{\mathrm{T}}\end{array}$ & 20 & TNP & TNP \\
\hline S. urinalis CCUG $41590^{\mathrm{T}}$ & 10 & $\mathrm{TNP}$ & TNP \\
\hline S. pyogenes ATCC $12344^{\mathrm{T}}$ & 21 & TNP & TNP \\
\hline S. parauberis CCUG $39954^{\mathrm{T}}$ & 13 & $\mathrm{TNP}$ & TNP \\
\hline S. canis ATCC $43496^{\mathrm{T}}$ & 22 & TNP & TNP \\
\hline
\end{tabular}

${ }^{*} \mathrm{RBR}$ (relative binding ratio) was determined by the following equation (percentage DNA bound to hydroxyapatite in heterologous reactions)/(percentage DNA bound in homologous reactions) $\times 100$. Calculation of $D$ (percentage divergence) assumed that a $1 \%$ decrease in thermal stability of a heterologous DNA duplex compared with that of the homologous duplex was caused by $1 \%$ unpaired bases; TNP, test not performed. 
S. ictaluri is also unknown, but as other fish-pathogenic streptococci have been transmitted to humans (Lehane \& Rawlin, 2000; Facklam et al., 2005), there is cause for concern that this organism could pose a potential health threat to aquaculture workers and recreational fisherman. Food safety is another potential human health concern (Ghittino et al., 2003). However, these questions can only be answered by accurate methods for identification of the species.

\section{Description of Streptococcus ictaluri sp. nov.}

Streptococcus ictaluri (ic.ta.lur'i. N.L. gen. masc. n. ictaluri of/from Ictalurus, the catfish from which the organism was isolated.)

Cells are Gram-positive cocci that occur in pairs or short chains, catalase-negative, do not produce haemolysis or pigment when grown on trypic soy agar supplemented with $5 \%$ defibrinated sheep blood, and are susceptible to vancomycin. Strains are positive for PYR and leucine aminopeptidase activity, and produce acid from maltose and ribose. Strains are negative for arginine, hippurate, aesculin and urea hydrolysis, growth at $45^{\circ} \mathrm{C}$, growth in $6.5 \% \mathrm{NaCl}$ broth and pyruvate utilization. Acetoin is not produced and tellurite is not tolerated. Using the rapid ID32 Strep test system, alkaline phosphotase, alanine-phenylalanineproline arylamidase and pyroglutamic acid arylamidase are produced. Arginine dihydrolase, $\beta$-glucosidase, $\beta$ galactosidase, $\beta$-glucuronidase, $\alpha$-galactosidase, $N$-acetyl$\beta$-glucosaminidase, glycine-L-tryptophan arylamidase, $\beta$-mannosidase and urease are not produced. Hippurate is not hydrolysed. Acid is not produced from ribose, mannitol, sorbitol, lactose, trehalose, raffinose, sucrose, L-arabinose, D-arabitol, cyclodextrin, glycogen, pullulan, maltose, melibiose, melezitose, methyl- $\beta$-D-glucopyranoside and tagatose. The natural habitat is unknown.

The type strain is $707-05^{\mathrm{T}}\left(=\mathrm{S} 02-1108^{\mathrm{T}}=\mathrm{ATCC}\right.$ BAA$1300^{\mathrm{T}}=$ CCUG $\left.52536^{\mathrm{T}}\right) ; \mathrm{G}+\mathrm{C}$ content is $38.5 \mathrm{~mol} \%$. Strains 705-05 (=S04-782-1), 706-05 (=S04-045) and $707-05^{\mathrm{T}}$ are distinguished by $16 \mathrm{~S}$ rRNA gene sequencing.

\section{Acknowledgements}

We are grateful to H. G. Trüper for assisting with the species epithet.

\section{References}

Baeck, G. W., Kim, J. H., Dennis, K. G. \& Park, S. C. (2006). Isolation and characterization of Streptococcus sp. from diseased flounder (Paralichthys olivaceus) in Jeju Island. J Vet Sci 7, 53-58.

Baya, A. M., Lupiani, B., Hetrick, F. M., Roberson, B. S., Lukacovic, R., May, E. \& Poukish, C. (1990). Association of Streptococcus sp. with fish mortalities in the Chesapeake bay and its tributaries. J Fish Dis 13, 251-253.
Brenner, D. J., McWhorter, A. C., Leete Knutson, J. K. \& Steigerwalt, A. G. (1982). Escherichia vulneris: a new species of Enterobacteriaceae associated with human wounds. J Clin Microbiol 15, 1133-1140.

Chang, P. H. \& Plumb, J. A. (1996). Histopathology of experimental Streptococcus sp. infection in tilapia, Oreochromis niloticus (L.), and channel catfish, Ictalurus punctatus (Rafinesque). J Fish Dis 19, 235-241.

Facklam, R. R. \& Elliott, J. A. (1995). Identification, classification, and clinical relevance of catalase-negative, gram-positive cocci, excluding the streptococci and enterococci. Clin Microbiol Rev 8, 479-495.

Facklam, R. R., Elliott, J. A., Shewmaker, L. \& Reingold, A. (2005). Identification and characterization of sporadic isolates of Streptococcus iniae isolated from humans. J Clin Microbiol 43, 933-937.

Freney, J., Bland, S., Etienne, J., Desmonceaux, M., Boeufgras, J. M. \& Fleurette, J. (1992). Description and evaluation of the semiautomated 4-h Rapid ID 32 Strep method for identification of streptococci and members of related genera. J Clin Microbiol 30, 2657-2661.

Ghittino, C., Latini, M., Agnetti, F., Panzieri, C., Lauro, L., Ciappelloni, R. \& Petracca, G. (2003). Emerging pathologies in aquaculture: effects on production and food safety. Vet Res Commun 27 (Suppl. 1), 471-479.

Hoshina, T., Sano, T. \& Morimoto, Y. (1958). A Streptococcus pathogenic to fish. J Tokyo Univ Fish 44, 57-68.

Kumar, S., Tamura, K. \& Nei, M. (2004). MEGA3: integrated software for Molecular Evolutionary Genetics Analysis and sequence alignment. Brief Bioinform 5, 150-163.

Lehane, L. \& Rawlin, G. T. (2000). Topically acquired bacterial zoonoses from fish: a review. Med J Aust 173, 256-259.

Mandel, M., Igambi, L., Bergendahl, J., Dodson, M. L., Jr \& Scheltgen, E. (1970). Correlation of melting temperature and cesium chloride buoyant density of bacterial deoxyribonucleic acid. J Bacteriol 101, 333-338.

Nomoto, R., Munasinghe, L. I., Jin, D. H., Shimahara, Y., Yasuda, H., Nakamura, A., Misawa, N., Itami, T. \& Yoshida, T. (2004). Lancefield group C Streptococcus dysgalactiae infection responsible for fish mortalities in Japan. J Fish Dis 27, 679-686.

Perera, R. P., Johnson, S. K., Collins, M. D. \& Lewis, D. H. (1994). Streptococcus iniae associated with mortality of Tilapia nilotica $\mathrm{x} T$. aurea hybrids. J Aquat Anim Health 6, 335-340.

Perera, R. P., Fiske, R. A. \& Johnson, S. K. (1998). Histopathology of hybrid tilapias infected with a biotype of Streptococcus iniae. J Aquat Anim Health 10, 294-299.

Plumb, J. A., Schachte, J. H., Gaines, J. L., Peltier, W. \& Caroll, B. (1974). Streptococcus sp. from marine fishes along the Alabama and Northwest Florida coast of the Gulf of Mexico. Trans Am Fish Soc 103, 358-361.

Robinson, J. A. \& Meyer, F. P. (1966). Streptococcal fish pathogen. J Bacteriol 92, 512.

Romalde, J. L., Magarinios, B., Villar, C., Barja, J. L. \& Toranzo, A. E. (1999). Genetic analysis of turbot pathogenic Streptococcus parauberis strains by ribotyping and random amplified polymorphic DNA. FEMS Microbiol Lett 179, 297-304.

Shewmaker, P. L., Steigerwalt, A. G., Morey, R. E., Carvalho, M. G. S., Elliott, J. A., Joyce, K., Barrett, T. J., Teixeira, L. M. \& Facklam, R. R. (2004). Vagococcus carniphilus, sp. nov., isolated from ground beef. Int J Syst Evol Microbiol 54, 1505-1510.

Teixeira, L. M., Facklam, R. R., Steigerwalt, A. G., Pigott, N. E., Merquior, V. L. C. \& Brenner, D. J. (1995). Correlation between phenotypic characteristics and DNA relatedness within Enterococcus faecium strains. J Clin Microbiol 33, 1520-1523. 